\title{
Explaining Gubernatorial Stability in Iowa: \\ A Review Essay and Author's Response
}

\section{Review Essay by James C. Larew*}

Gubernatorial Stability in Iowa: A Stranglehold on Power, by Christopher W. Larimer. New York: Palgrave Macmillan, 2015. xii, 164 pp. Tables, graphs, charts, notes, appendix, bibliography, index. $\$ 67.50$ hardcover.

NEAR THE END OF HIS BOOK, Gubernatorial Stability in Iowa: A Stranglehold on Power, Christopher W. Larimer poses the question that he has attempted to answer: Until Terry Branstad stepped down as governor in 2017, Iowans had been governed by just four different men for the past 50 years. Why such stability? More specifically, "the purpose of this book," Larimer writes, is "to explore gubernatorial power in Iowa drawing on established research about the formal and informal powers of governors ... as well as what some scholars have described as the idiosyncratic influences on gubernatorial approval'" (133).

For the political scientist, Iowa, a stable place by many measures, is a fertile place to test hypotheses, an apt venue to address the type of question that Larimer's book attempts to answerwhy has there been such stability in the governor's office? As if a political petri dish, the state provides a relatively steady human and institutional laboratory in which to conduct political science

*James C. Larew is an attorney in the private practice of law in Iowa City. He served as general counsel and chief of staff to Iowa Governor Chet Culver.

THE ANNALS OF IOWA 76 (Summer 2017). (C) State Historical Society of Iowa, 2017. 
experiments, to explore events, to evaluate processes, to test theories, and to attempt to isolate and test variables drawn from the past half-century of its history. During that time period, Iowa's population of approximately 3 million people, although gradually growing older and shifting from rural to urban and west to east, remains largely unchanged, dispersed among more than 950 towns and cities located in 99 counties. No one region in Iowa dominates others; political organizations are created to face the challenges of one election cycle, only to be dissipated immediately thereafter. No political machines in Iowa determine the fates of Iowa office seekers; there are no rotten boroughs to distort election outcomes. Iowa's computer-driven, nonpartisan method of legislative apportionment virtually eliminates the contortions caused by the shenanigans of gerrymandering that affect the political cultures of many other states. Finally, even though the exercise of executive branch powers by the Governor's Office has gradually increased in the past five decades, it is also the case that the basic architecture of the state's constitutional framework has scarcely been altered since a series of fundamental reforms occurred in the historic 1965-66 session of the Iowa General Assembly.

Larimer, associate professor of political science at the University of Northern Iowa, approaches his subject-Iowa's unusual pattern of gubernatorial officeholder longevity - through three principal avenues of inquiry, each the focus of a separate chapter. First, he reviews "approval data" drawn from data banks assembled by political scientists as applied to Iowa's past governors. Second, he presents interviews with political activists, observers, and two of the governors - Thomas J. Vilsack and Branstad - who are the focus of his study. Third, he undertakes an original statewide study of 188 Iowa voters who were asked, retrospectively, to evaluate the performances of Governors Branstad, Vilsack, and Chet Culver. To close his study, Larimer describes potential implications of his findings for politicians operating in the Iowa arena and points to possible future areas of social scientific research.

The author's approach in analyzing the causes of Iowa's pattern of gubernatorial longevity is leveraged on one counter-example: one-term (2007-2011) Governor Culver's re-election loss, in 2010, which established him as only the second Iowa incumbent 
governor in the last half-century to have lost a re-election bid (the other, Republican Governor Norman Erbe, lost to Democrat Harold E. Hughes in 1962 after serving for one two-year term). All other incumbent governors since Hughes's election in 1962Robert D. Ray, Branstad, Vilsack, and, again, Branstad - were either re-elected or chose to retire. ${ }^{1}$ Given this unique "stranglehold" history, a primary goal of Larimer's is to identify characteristics of Governor Culver that may have caused his defeat.

To explain Culver's re-election loss as opposed to the re-election victories of others, Larimer first considers, but rejects, economic and political constraints: declines in state and national economic conditions; increased state unemployment rates when compared to national rates; a shared party affiliation between a governor and an unpopular sitting president; and whether a governor presides over legislative chambers whose partisan majorities are unified or divided. Upon concluding that all recent governors faced similar economic and political constraints, Larimer turns to his own interviews of political operatives and observers. He determines that Culver's personal characteristics were the distinguishing factors that resulted in his singular defeat.

Larimer's conclusion is based on impressionistic interviewbased research he conducted (chap. 3). No set of questions appears to have been asked of all of the interviewees - or, at least, no evidence of that approach is presented. From these interviews, however, Larimer concludes that, in Iowa, a governor who is perceived to have traits and behaviors that include "working hard" and "trying" and being "out there" and who has the ability to "connect" with voters also achieves a level of what the author terms "Iowa comfort." Many interviewees (some of them anonymous) were particularly harsh in their assessment of Culver's capacity to "work hard," and some even pointed to that perceived personal shortcoming as the basis for his electoral defeat in 2010. By contrast, the author appears to imply, Governor Branstad's re-election in 1986 in the midst of a rural economic recession can be attributed to his image as a "hard worker."

1. Robert Fulton served briefly as governor when Hughes resigned shortly before his third term ended so that Hughes could gain a seniority advantage over his peers in the U.S. Senate, to which he had just been elected, and Fulton, then lieutenant governor, was elevated briefly to the governor's chair. 
This impressionistic phase of Larimer's research is followed by his analysis of his own polling efforts. Starting with approximately 1,200 voters to whom questionnaires were initially sent, Larimer ends up with 188 responses from Iowa voters of a certain age (at least old enough to have voted for Branstad, Vilsack, and Culver), divided thinly over four separate congressional districts. Here, and based on impressions he gained in the interviewing process described in chapter three, Larimer creates and explores two conceptual gubernatorial capacities: "management powers" (related to executive management functions) and "connecting powers" (relating to outreach and constituent relations functions). Larimer finds that each governor enjoyed favorable ratings by those who shared his party affiliation but that among Democrats, Vilsack received higher ratings than Culver for "management" and "connecting powers." In an interesting contrast to the interviewees in chapter three, the 188 survey respondents concluded, when comparing attributes ("communicate effectively," "working hard," "effort to meet Iowans," "good representative," and "clear vision"), that the characteristic that least differentiated Culver, Vilsack, and Branstad was the capacity to "work hard" (118).

In summarizing his findings (chap. 5), the author concludes that while traditional models of gubernatorial popularity, such as economic factors, explain some of the "staying power" of Iowa's governors, "so do perceptions about the governor's desire to work hard on behalf of all Iowans." "Governors who are perceived as working hard, being out and about around the state," Larimer postulates, "are given some slack during tough economic times." He further conjectures that, while approval ratings may decline, "voters are less likely to hold a governor accountable at the polls if they hold a favorable impression of that governor's work ethic on behalf of the state" (13). Larimer concludes,

There is more to it than just correlations between public opinion and the "fundamentals" of the political system such as presidential approval and aggregate level measures of the economy. For Governor Culver, there was a clear disconnect between what voters have come to expect of their governor and the actions they perceived coming out of the Culver administration.... Culver ... didn't give off the perception of liking his job or regularly interacting with voters. For an electorate that takes politics very personally and expects 
"government officials [to be] approachable on a personal basis" ... this was a problem (14).

The author concedes, as an aside, that Governor Culver's loss in 2010 was not inconsistent with "existing models" of "gubernatorial popularity" and may be traced to the impact of events external to Culver's personality traits, "a remarkable confluence of events, including backlash against a 2009 Iowa Supreme Court ruling allowing for same sex marriage in Iowa, the Tea Party movement, a significant economic downturn and perhaps most notable, a challenge from a former governor - an unprecedented occurrence in Iowa" (9). Nevertheless, to Larimer, more "unconventional" or "less easily observed constraints," such as the ability to convey a sense of "Iowa comfort," principally explain the differences between Governors Ray, Branstad, and Vilsack's respective abilities to win re-election and Culver's failure to do so (13).

While Larimer's analysis results in a series of useful observations about Iowa's recent political history, it is nevertheless unsettling that he fails to address in any meaningful way the impact of the three most dominating and adverse of the "remarkable confluence of events" of the Culver years, the events most apt to have challenged Culver's performance in office and to have shaped the public's opinion of his gubernatorial efforts: (1) the Great Flood of 2008; (2) the Great Recession, causing an extraordinary contraction of Iowa's economy and tax base, starting in 2009; and (3) adverse public reaction and political response to President Barack Obama's policy initiatives in 2008-2009.

Instead of exploring any of these history-bending events in his analysis, Larimer proposes that Culver's predecessors each faced challenges similar to Culver's and yet they, unlike Culver, overcame such challenges to win re-election. Given these contrasting outcomes, Larimer surmises, something must be "missing from existing models of gubernatorial popularity that can help to explain this recurrent pattern [of gubernatorial longevity] in Iowa" (9). Ultimately, Larimer concludes that Culver's failure to win re-election turned on what might be characterized as "internal" factors of political personality (Larimer's "connecting powers") and style ("management powers") rather than on the profound "external" factors that constitute the currents of history. But currents flowing from a "confluence" of these "remarkable" 
events that evade Larimer's analysis are the very types of factors that can affect electoral outcomes and that, in fact, did influence the 2010 gubernatorial election in ways that were at least as pronounced.

For example, first, the devastating Great Flood of 2008, the largest natural disaster in the state's history, covering more than one-third of the state, inflicted its deepest damage in the central and eastern Iowa cities and counties whose electoral margins had provided Culver's statewide winning difference in 2006. In June 2008, the rivers of eastern Iowa rose above their banks, covering farmlands, closing transportation routes, and displacing thousands of residents and hundreds of businesses. Water more than 20 feet deep flowed through downtown Cedar Rapids, as citizens battled against the Cedar River's currents and witnessed the ruination of residential, industrial, and business districts. Thirty miles away, in Iowa City and Coralville, the Iowa River's flooding was the most destructive in recorded history, destroying businesses, forcing the evacuation of homes, and closing down the University of Iowa. Further southeast, where the Cedar and Iowa Rivers merge, were sites of unprecedented water levels and resulting flood damage.

Although the Iowa Governor's Office is constitutionally limited in its ability to invoke the powers of government unilaterally, Culver, in a series of executive orders, reorganized state government agencies to focus state resources on flood mitigation efforts. Executive Order No. 7, for example, issued on June 27, 2008, established a Task Force to Rebuild Iowa and a new Rebuild Iowa office. A little later, on November 7, 2008, in Executive Order No. 9, Culver broadened and defined state agency powers to coordinate federal relief efforts with state agencies. Initially, his visible, activist response to flood crises was favorably viewed by Iowa residents.

But when the murky flood waters finally receded, largely from the state's most Democratically inclined counties in eastern and central Iowa, they left behind more than dark stains of nauseating mud and scattered debris. They also left behind altered and chastened views about the relationships of citizens to those who governed them. In the days and weeks after the flood waters crested, citizens were frequently without power, and even those who were not displaced from their homes were deprived of normal 
routines. Those whose businesses were destroyed or damaged were often left without livelihoods.

Catastrophic events change lives irrevocably. There are stages of disaster response: heroic and adrenalin-filled rescues and relief efforts followed by long, painful, anxious periods of recovery. There is a tension that grows between the depth of needs of persons in times of danger and what bureaucracies can later deliver by way of effective relief. What initially seem to be sudden and ruthless acts of God or Nature are translated, later, into questions about whether government is able to provide desperately needed assistance or whether, instead, citizens are at the mercy of a broken system, run by people who appear to be indifferent to suffering.

Ecological trauma is felt in the individual body; it is also shared in the body politic. Citizens discover both their own limited capacity to provide relief to others and the slow, limited capacity of government to address lingering difficulties. In this sense, it is a fiction to conceptualize that those devastated by the floods were ever in an "after disaster" mode during any of the remaining years of the Culver Administration. The impacts of the Great Flood were ever-present: they were dispiriting; they were exhausting; and, eventually, they took a heavy toll on Governor Culver's favorability ratings.

The second great event of the Culver years, the Great Recession of 2008-2010, is barely mentioned by Larimer. It was not a mere footnote to history: it was a downward-driving force of history itself. In the last quarter of 2008 - at a time when scarce state resources were desperately needed to remediate flood damagestate revenues started to contract and, on December 22, 2008, Governor Culver instituted the first of what would be a series of executive orders mandating across-the-board reductions in state spending due to shortfalls in tax revenue collections. In Executive Order No. 10, issued on December 22, 2008, he ordered a 1.5 percent reduction in spending. But the recessionary pressures did not let up; they only intensified. In the months ahead, tax revenues would drop precipitously - particularly in those areas related to the state's basic industrial businesses.

Within nine months of Culver's initial across-the-board budget cut, in Executive Order No. 18, issued on September 25, 2009, he 
ordered the transfer of $\$ 45.3$ million to allow the closure of the state's book for the 2009 fiscal year. And, only a few weeks after that, on October 8, 2009, Culver ordered an unprecedented 10 percent across-the-board cut in all state agencies to cope with the deeply reduced collection of taxes. These were unprecedented, forceful, activist uses of the governor's powers, ones that allowed government agencies to function in difficult times, but all of them resulted, directly or indirectly, in adverse consequences for those who worked for and who relied on the delivery of government services. In addition to public sector contractions, in the private sector, unemployment rates rose across the entire state. Iowa's manufacturing sector, in particular, shrank, throwing blue-collar workers out of work and exposing thousands of Iowans - many of them residing in the very areas that had been savaged by flood waters - to new threats of dispossession of their businesses and homes.

The third history-bending event, also scarcely alluded to by Larimer, involved Iowans' adverse reactions to Democratic President Barack Obama's federal policy initiatives. Elected by a majority of hopeful Iowans in 2008, Obama pushed through what would prove to be deeply unpopular federal programs. From Inauguration Day in 2009 until July 2010, the Obama White House oversaw the passage of (1) the stimulus package, the most expensive piece of legislation in American history; (2) the second half of the TARP-TALF financial-bailout bill; (3) the Dodd-Frank financial regulatory reforms; and (4) the Affordable Care Act, otherwise known as Obamacare. Not since 1933 had there been a more aggressive legislative and regulatory agenda, and Obama's determined march featured not only $\$ 2.7$ trillion in new spending but also the wholesale revision of the nation's health-care system. It was, for many distressed Iowans, as well as for people living in other regions of the nation, too much, too fast, and too soon. For others, those perched on the other end of the political spectrum, Obama's program was too little, too slow, and too late. Many citizens viewed his advisers as at least in part responsible for the deregulation of Wall Street that had caused the Great Recession. Obama was therefore seen by many as bailing out banks and investment firms at public expense while demanding too little in return -no breakups of the banks, no separations of commercial 
and investment banking combinations, no meaningful curbs on executive pay and bonuses in the finance industry, and too little help for homeowners unable to afford mortgage payments on houses whose values had collapsed. Thus, in Iowa, the period of Culver's diminishing popularity was also a time of mounting anger and frustration for many-significant numbers of whom had been Culver's earlier supporters. Obama's federal policies inflamed political seethings that would find expression in the 2010 elections and would foreshadow profound changes in Iowa's political landscape (as well as in the nation's) in the years to follow.

Each of these three separate ground-shifting events-the Great Flood, the Great Recession, and adverse responses to Democratic President Obama's federal programs-challenged the strength and powers of the Governor's Office itself - to say nothing of Culver's individual ability to exercise the limited powers of that office in response to them. Collectively, the events wove together the unique backdrop against which Iowans measured Governor Culver's performance, a backdrop unlike any that had draped the administrations of his gubernatorial predecessors in the previous 80 years. By failing to address this reality, Larimer's approach to evaluating Iowa's pattern of gubernatorial longevity causes him to suggest that the critical differences between the successful re-elections of Hughes, Ray, and Branstad, on the one hand, and Culver's loss in 2010, on the other hand, can be found in a comparison of each governor's respective leadership capacities.

A central fact cannot be denied: Governor Culver lost-and by a significant margin (53 to 43 percent) -in the 2010 election after having won four years earlier by nearly the same margin (54 to 44 percent). There was an astonishing cumulative swing in the electorate of nearly 20 points in four years. Defining just how, when, where, and by which types of voters this erosion principally occurred can provide some indication as to why it happened. But these are not the issues that Larimer has chosen to explore in any depth.

Measurements of public opinion taken in real time and in the context of real processes and real events over a course of years suggest that the erosion of support was caused more by powerful external events than by personality traits unique to Culver. Global Strategies Group, a polling operation based in New York 
City, was retained as Governor Culver's campaign pollster for the 2006 campaign. It continued to perform polling services periodically thereafter. Those polls, taken repeatedly from May 2007 through October 2010, provided a constant measuring device over time. They revealed that Culver enjoyed strong popularity in the opening year of his administration (achieving, in fact, higher marks in that year than Governor Branstad ever would through November 2010), and, then, built on that strength by his visible on-the-ground presence and exercise of executive powers in response to the Great Flood. By December 2008, for exampleincluding months of activism via the issuance of executive orders aimed at flood relief efforts - Culver's approval rating increased to 64 percent as a statewide average. This included significantly higher approval ratings in the badly flooded Iowa City-Cedar Rapids media area (66 percent approval rating) and in northeast Iowa counties (69 percent) than in areas less severely affected by flooding. Among politically independent male voters, Culver was particularly well supported during this time frame (69 percent).

Those favorability ratings did not hold, though. In the midst of the tiring effects of flood mitigation, in the five-month period between December 2008 and May 2009, Culver's favorability ratings among Iowans flipped and crashed-never to return to the higher levels of support, and were subject to continued decline thereafter.

There is no evidence to suggest that Culver's personality had changed in that short time frame. And it does not seem plausible that such factors as "working hard" or "trying" or conveying a persona of "Iowa comfort" - concepts developed in Larimer's work - explain the dramatic turn of events. A more likely explanation for the downturn in Culver's popularity is that his political fortunes, at first anchored in residuals of flood relief efforts, were increasingly tied to other forces, not the least of which were recessionary pressures that could not be contained by state government initiatives. Federal programs launched by a president who shared Culver's political affiliation, ones aimed to alleviate economic suffering caused by the Great Recession, were viewed unfavorably by a wide spectrum of Iowa voters. Over the remaining years of Culver's administration, as opposition to President Obama's economic policies grew, Culver's political fortunes waned. 
All of this coincided with insurgent political energies that arose from multiple points on the political spectrum, forms of expression sometimes collectively known as the Tea Party movement. That insurgency found its most immediate political expression in the 2010 mid-term elections. At the federal level, it would cost the Democrats 63 House seats, the largest such defeat in 72 years. At state houses, more than 600 legislative seats would change hands from Democrats to Republicans. And, in Iowa, the longevity string of successful gubernatorial incumbent re-elections would be broken.

Can it credibly be argued that Culver's demise was caused by his failure to meet challenges that were comparable to those faced by his predecessors, by an electorate that found him wanting in the exercise of "management powers" and "connecting powers" when facing those challenges? It would seem more convincing to argue that the 2010 election marked less a public measure of Governor Culver's character traits, as the Larimer study suggests, than that it represented a "stress test" on Iowa's political culture. That test challenged foundational concepts ranging from the state's longstanding tradition of gubernatorial longevity (by voting Culver out of office) to citizens' normal deference to the state's judiciary (by voting out of office, in the 2010 election, for the first time in the state's history, three supreme court justices, a response to that court's controversial ruling finding same-gender marriage to be constitutionally protected). And, as subsequent election cycles would show, Iowa's 2010 political stress test would be only the first of a series of such tests, experienced first in other states and then in the 2012 presidential election, almost all of them related in some way to the Obama administration and ultimately resulting, six years later, in 2016, in the advent of Trumpism.

Culver's 2010 gubernatorial loss reflected, in large part, the deep erosion of his political support in those areas of central and eastern Iowa where, in 2006, he had received some of his strongest backing but that had been most adversely affected by the combined traumas of the Great Flood, the Great Recession, and adverse reactions to Obama's federal initiatives. When comparing Culver's margins of victory and margins of defeat on a county-by-county basis, the adverse shifts in these areas were particularly remarkable. 
In retrospect, Culver's 2010 loss would also serve as a premonition, the cutting edge of a six-year wave of Democratic Party officeholder attrition during which there would be other losses, including a 35 percent reduction in the number of Democratic governors elected to office. Seen in that vein, Culver's re-election loss, his breaking of Iowa's gubernatorial "stranglehold of power," was not a referendum on the personality or style of a particular person holding that office at a particular moment in time; rather, the election result placed a point on a graph and joined a trend line that had started a year before and that would continue through the remaining Obama years.

In 2009 Democrats held 31 governorships. By the end of Obama's presidency, they would hold only 17. By then, too, Republicans would control all levels of government in 25 states. In a manner unprecedented in American history, during the Obama presidency more than 1,100 Democratic elected state legislative officeholders would lose their jobs to Republicans. At the federal level, by 2016, Republican majorities would control both chambers of Congress and the presidency itself, captured by the most unlikely Republican candidate of them all: Donald J Trump.

In light of these factors, it can and must be conceded that Christopher Larimer has added valuable insights into how Iowans perceive their governor and how, under normal conditions, those who seek or who hold that office might conduct themselves to obtain and to hold the support of the voting public. However, it must also be said that any comparative analyses made about the performance of any one Iowa governor, as compared to the performances of others, must involve a careful scrutiny of fundamental premises and must not oversimplify or distort the challenging context in which any such person privileged to serve in that office has exercised its powers and duties.

\section{Response by Christopher W. Larimer}

I appreciate James Larew's review of my research on Iowa governors, particularly given his own record of involvement in the highest levels of state government. For those interested in a historical account of modern party competition in Iowa, I recommend Larew's book, The Party Reborn, which discusses how key 
figures such as Harold Hughes and John Culver revitalized the modern Democratic Party in Iowa.

Larew's main point of contention is that I put too much emphasis, or place too much blame, on Governor Culver's personal attributes, ignoring other seemingly obvious environmental factors. On several occasions, Larew refers to my analysis as "impressionistic" and speculative, as well as a significant departure from political reality. This critique is inaccurate for three reasons. First, my analysis is not based on a reading of Culver personally but rather perceived differences between Culver and his predecessors as indicated by Iowa voters and nearly two dozen longtime observers of Iowa politics. Larew writes that my analysis shows that "Culver's personal characteristics were the distinguishing factors that resulted in his singular defeat." That is a misunderstanding of my analysis. As I write very clearly in the conclusion, "It may very well have been that Governor Culver was doing as much as (or more than) Branstad or Vilsack, but the perception was that he was not" (134, italics added).

Second, my conclusions derive from an evidence-based approach to understanding gubernatorial popularity. As I discuss in this response, most of the shortcomings described by Larew are covered and controlled for in the statistical analyses presented in chapters 2 and 4 and the appendix of my book.

Third, and perhaps most damning, Larew's critique suggests that my interpretation of the findings exceeds the bounds of the data. As this response will attempt to make clear, that is not the case as my conclusions are well situated within the parameters of the data.

Larew is highly critical of what he calls the "impressionistic phase" of my research, specifically the results from interviews I conducted with longtime observers of Iowa politics. Larew writes, "No set of questions appears to have been asked of all of the interviewees - or, at least, no evidence of that approach is presented." Table A3.1 in the appendix does, in fact, include the set of questions that were asked of all interviewees, the purpose of which was to provide a formal comparison across all responses.

The second half of Larew's essay focuses on three alternative explanations for Culver's defeat in 2010: the flood of 2008, the Great Recession of 2008-2010, and the backlash to President 
Obama's policy agenda. Larew argues that the combination of these factors contributed to Culver's defeat and that my analysis ignores their overwhelming influence. I agree with Larew that such factors are important to consider; however, the linear models presented in chapter 2 directly address and account for two of these factors while the third is inconclusive.

First, the regression model in table 2.4 on page 55 casts doubt on the claim that economics and presidential politics are solely to blame for Culver's defeat. My purpose for writing the book was to try to understand whether there was something unique about the way voters perceived Governor Culver compared to Governors Ray, Branstad, and Vilsack. As a political scientist, I was also interested in testing whether traditional explanations for gubernatorial popularity, such as state economic factors and shared party affiliation with an unpopular president, applied to Iowa governors. The model shown in table 2.4 controls for all three sets of factors. Specifically, and critical to addressing Larew's claims, I included three binary variables for Governors Ray, Branstad, and Vilsack. Governor Culver is left out as the comparison governor. If these three variables are significant and in the same direction, then it would suggest that there is an independent and unobserved effect beyond economics or politics for each of these three governors compared to Governor Culver. Indeed, that is exactly what the model shows, as the coefficients for all three variables are significant and positive. In other words, the coefficients are telling us that even when controlling for federal and relative unemployment, as well as shared party affiliation with the president, which is tied to ups and downs in presidential approval, just being Robert Ray, Terry Branstad, or Tom Vilsack is correlated with significantly higher approval ratings compared to Chet Culver. That is the case even when accounting for changes in federal and state unemployment rates and presidential approval. This is precisely the point of doing the interviews, to understand what is causing the approval ratings of Ray, Branstad, and Vilsack to be significantly higher than for Culver, as the data suggest that it is not economics or politics. On this last point, this indicates that even if Obama's policy agenda "inflamed political seethings," as Larew writes, the model shows that some other factor, not yet considered, significantly affected gubernatorial 
approval ratings between governors. Likewise, if it is economic frustration that turns voters away from Iowa governors, the two economic variables in table 2.4 should have consumed more of the variance in the model, rendering the three binary variables for individual governors insignificant. That was not the case.

On the economy, I would add that figure 1.2 on page 28 shows that the correlation between approval ratings and unemployment rates was strong and significant (and negative) for both Governor Vilsack and Governor Culver. To Larew's point, the negative correlations for Culver were greater than for Vilsack, but only marginally so for state unemployment (0.10). Since research has shown that voters tend to think about state economic factors more so than national economic factors when voting for governor, the marginal difference between the two governors suggests that Culver was not punished unusually for downturns in the state's economy.

On Larew's second point, if voters were that upset with President Obama's policies, that should have shown up in the individual approval ratings model for Governor Culver in table 2.6 on page 63. The variable for presidential approval, while negative, is not significant. As such, Larew's argument that bad feelings toward President Obama's agenda in 2010 directly contributed to Culver's defeat is not supported by the empirical evidence presented in the chapter. I do agree with Larew that resentment toward Obama in 2010 existed, and that the Tea Party movement likely exacerbated such resentment toward Democratic candidates generally at the time, but at least as measured by presidential approval, I do not find evidence showing that this affected Culver's popularity.

In short, Larew's statement that I have not explored these issues "in any depth" is not supported by the analyses presented throughout chapter 2 . In fact, footnotes $11-15$ on pages $72-75$ discuss the many variations and iterations tested for predicting changes in gubernatorial popularity. The results presented in the chapter are highly robust and hold across model variations.

One final note on the statistical aspects of gubernatorial popularity. Larew's point about declining favorability in key counties in the months after the 2008 flood are well taken, but suggesting that declining support and turnout in those counties can be directly attributed to flood-related issues or "recessionary pressures" 
risks making an ecological fallacy - using aggregate level data to make assumptions about individuals. It may have been the case that some voters fit with Larew's categorization, but the data, to my knowledge, do not exist to empirically support his claim. Polling from within campaigns such as that from Global Strategies Group cited by Larew can be useful but should always be treated with caution until full details about voter selection and randomization are known.

Larew's second main criticism is that my analysis is onesided, that the perceived shortcomings on what I call "connecting powers" are the primary explanation for Culver's defeat. I devote considerable attention to other factors that likely combined with a perceived weakness on connecting with voters. The two most notable, which Larew fails to discuss, are the strength of the challenger and the dangers of unified control. Opponent strength is discussed at length on pages 34-37 and 98-101, and table 1.3 shows that Culver's re-election bid was unprecedented in this regard. I would also direct the reader to the quote from Dean Borg on page 101, who said that against "a very weak Republican, Culver might have been reelected." A perceived ability to connect with voters matters, but so does the strength of your opponent. Culver was also tasked with dealing with unified state government, and as research as shown, when times are bad, the chief executive tends to be the focus of the public's ire. Neither Branstad nor Vilsack had to deal with unified party control for an extended period of time (Vilsack never had to).

Finally, in terms of the results from my statewide survey of Iowa voters, I agree with Larew that the response rate of 12.5 percent and resulting sample size of 188 voters was less than ideal. However, his critique and dismissal of the data ignore two crucial statistical components of my analysis. First, while the response rate was low, the entire universe of voters from which the sample was drawn included all active voters in the state as provided in the official voter file from the Iowa Secretary of State's office. From there, 375 voters within each district were randomly selected to be sent a survey, for a total of 1,500 potential respondents (not 1,200 as Larew stated). The randomization was done such that within each congressional district those selected to receive a survey did not differ from those not selected on several 
important traits pertaining to political behavior, including vote history in three previous elections (November 2010, November 2008, and November 2006), political party identification, sex, age, and household size. As shown in table A4.2 in the appendix, within each congressional district there were no differences on these traits between voters selected to receive the survey and those not selected. Multinomial logit tests using those six variables to predict selection to receive the survey were also nonsignificant in each congressional district. Moreover, between survey respondents and voters selected to receive the survey but who did not return it, there were few differences within each district. As reported on pages 110-11, these differences are primarily limited to turnout in the November 2010 election, and within each district, turnout was higher for survey respondents. In other words, survey respondents comprise a more active (and likely more politically aware) group of voters.

So, despite the small sample and being "divided thinly over four congressional districts," as Larew writes, there is enough statistical support to be confident in my ability to generalize to a larger electorate regarding differences in what I call "management" and "connecting" powers of recent Iowa governors. Additional analyses discussed in the conclusion note that the perceived differences between Culver and Vilsack remained even after controlling for the observable characteristics of survey respondents. Finally, the sample of 1,500 active registered voters was restricted to voters who voted in the 2012 general election. As I wrote in the book,

The purpose of sampling 2012 voters who also voted in one of two recent general elections was to select Iowa voters who are actively involved in the political process and presumably pay more attention to Iowa politics on a regular basis as compared to infrequent or intermittent voters. And indeed this was the case as over 90 percent of respondents indicated they follow "what's going on in government and public affairs" most or some of the time (109).

Larew writes that the survey evidence discredits the results from the interviews since the differences between governors were the "least differentiated" on the question of "commitment to working hard on a daily basis for the people of Iowa." Larew is correct that of the five "connecting powers" identified in the book, the overall 
mean range between the three governors is the smallest on this question. However, this is somewhat misleading, as this argument looks past the fact that the differences between governors are all still statistically significant. In fact, between Governor Culver and Governor Vilsack the difference is at the .01 level of significance, while between Governor Culver and Governor Branstad it is at the .05 level of significance. Larew is essentially making a substance versus significance argument that does not hold up upon closer inspection. An alpha level of .05 is standard in the social sciences. Moreover, the true $\mathrm{p}$-values for the differences between governors on this question are 0.000 between Culver and Vilsack and 0.011 between Culver and Branstad. Put another way, the chances of the differences being due to random chance are less than 1 in 100 and approximately 1 in 100 . Technically the odds are different, but social scientists would likely agree that the chances are minimal in both cases. In short, while Larew questions this "retrospective" account given by voters, the results are statistically robust.

In the concluding paragraph of his essay, Larew suggests that my analysis has the potential to both "oversimplify" and "distort" the context facing Iowa governors. As I have laid out in this essay, that is a misreading of my approach. The statistical analyses presented in chapters 2 and 4 show that Culver was viewed and perceived differently than other governors, even when controlling for factors research has shown to be predictive of gubernatorial approval. Put another way, the linear models indicate factors beyond presidential politics and the economy affect gubernatorial popularity in Iowa. The interviews suggest perceived effort and comfortability may influence how voters view the chief executive of the state, and the survey data provide a first attempt at measuring those two concepts in the form of my "connecting powers" index.

In short, I agree with Larew that the atmospherics of the 2010 gubernatorial election were unusually bad for a Democratic incumbent; in fact, they were unprecedented in Iowa politics. However, I take issue with Larew's discounting of my research as "impressionistic." As I demonstrate here and throughout the book, the perceived differences between the three governors, based on approval ratings and survey responses, are empirically robust; I would point readers to the appendix for complete details. I 
would also again stress that the book was not based on the personal attributes of Governor Culver but rather the perceived personality traits of recent Iowa governors. The interviews were conducted with a consistent set of questions designed to get at what variables might be missing from existing research on gubernatorial popularity, and the results suggest that perceived differences in visibility and relatability are worthy of further exploration by scholars. I used the concluding chapter to lay out the beginnings of what such a theoretical framework might look like and encourage state politics scholars and others to think about how best to measure related concepts. 